\title{
Occurrence of wide-chain Ca-pyriboles as primary crystals in the Salton Sea Geothermal Field, California, USA *
}

\author{
Yu-Chyi Yau, Donald R. Peacor, and Eric J. Essene \\ Department of Geological Sciences, The University of Michigan, Ann Arbor, MI 48109, USA
}

\begin{abstract}
Amphiboles and pyroxenes occurring in the Salton Sea Geothermal Field were found to contain coherent intergrowths of chain silicates with other than double and single chain widths by using transmission and analytical electron microscopy. Both occur in the biotite zone at the temperature (depth) interval of $310^{\circ} \mathrm{C}(1,060 \mathrm{~m})$ to $330^{\circ} \mathrm{C}$ $(1,547 \mathrm{~m})$ which approximately corresponds to temperatures of the greenschist facies. The amphiboles occur as euhedral fibrous crystals occupying void space and are composed primarily of irregularly alternating $(010)$ slabs of double or triple chains, with rare quadruple and quintuple chains. Primary crystallization from solution results in euhedral crystals. Clinopyroxenes formed mainly as a porefilling cement and subordinately as prismatic crystals coexisting with fibrous amphiboles. Fine lamellae of double and triple chains are irregularly intercalated with pyroxene. AEM analyses yield formulae $\left(\mathrm{Ca}_{1.8} \mathrm{Mg}_{2.9} \mathrm{Fe}_{1.9} \mathrm{Mn}_{0.1}\right)$ $\mathrm{Si}_{8} \mathrm{O}_{21.8}(\mathrm{OH})_{1.8}\left(310^{\circ} \mathrm{C}\right)$ and $\left(\mathrm{Ca}_{2.0} \mathrm{Fe}_{2.5} \mathrm{Mg}_{2.3}\right) \mathrm{Si}_{8} \mathrm{O}_{21.8}$ $(\mathrm{OH})_{2.0}\left(330^{\circ} \mathrm{C}\right)$ for amphiboles and $\left(\mathrm{Ca}_{1.1} \mathrm{Fe}_{0.6} \mathrm{Mg}_{0.3}\right)$ $\mathrm{Si}_{2} \mathrm{O}_{6}$ for clinopyroxene. Thermodynamic calculations at $P_{\text {fluid }}=100$ bar of equilibrium reactions of (1) 3 chlorite +10 calcite +21 quartz $=3$ actinolite +2 clinozoisite $+8 \mathrm{H}_{2} \mathrm{O}$ $+10 \mathrm{CO}_{2}$ and (2) actinolite +3 calcite +2 quartz $=5$ clinopyroxene $+\mathrm{H}_{2} \mathrm{O}+3 \mathrm{CO}_{2}$ using $\mathrm{Mg}$-end member phases indicate that formation of amphibole and pyroxene require very water-rich conditions $\left(X_{\mathrm{CO}_{2}}<0.06\right)$ at temperatures below $330^{\circ} \mathrm{C}$.
\end{abstract}

\section{Introduction}

Although their structures were modeled theoretically by Thompson $(1970,1978)$, the wide-chain pyriboles with triple or wider chains such as chesterite and jimthompsonite (Veblen and Burnham 1978) were discovered only recently. They have been identified in experimental syntheses of amphiboles and micas (Drits et al. 1975; Tateyama et al. 1978; Maresch and Czank 1983a, b) and in alteration products of natural pyroxenes and amphiboles (Veblen and Buseck 1979, 1980, 1981; Nissen et al. 1980; Nakajima and Ribbe 1981; Akai 1982). Most examples are composed of either

\footnotetext{
* Contribution No. 420 from the Mineralogical Laboratory, Department of Gcological Sciences, University of Michigan, Ann Arbor, Michigan
}

Offprint requests to: D.R. Peacor triple chains or both double and triple chains occurring in regular or irregular alternation. Isolated slabs with variable chain widths are also found within fibrous amphiboles (Chisholm 1973; Hutchison et al. 1975; Jefferson et al. 1976; Veblen et al. 1977; Jefferson et al. 1978). A widechain Ca-pyribole has been found in natural hydrothermally altered clinopyroxene (Akai 1982) but has not yet been found in synthetic products.

Although the existence and structure of wide-chain silicates are well known, the conditions of their formation are only poorly understood. Veblen (1981) suggests that naturally occurring wide-chain pyriboles are typically produced by replacement reactions from pyroxenes and amphiboles. Nevertheless, an exsolution-like mechanism for fine lamellae of amphibole within pyroxenes that originally had some solid solution toward amphibole composition has been suggested (Desnoyers 1975; Smith 1977). To our knowledge, the primary growth of wide-chain silicates has never been reported in geological environments, although the triple chain structures within fibrous amphiboles described by Chisholm (1973) and Hutchison et al. (1975) may have had such an origin.

On the other hand, formation of wide-chain pyriboles synthesized under hydrothermal conditions implies that they should occur in analogous geological systems. On that basis we anticipated their occurrence in sediments from the Salton Sea Geothermal Field. We also surmised that the pyroxene formed in that environment would contain lamellae of amphibole or wide-chain pyriboles and accordingly searched for them. In this paper we report on observations of primary growth of disordered wide-chain pyribole in actinolite and clinopyroxene. Actinolite (and/or tremolite) and clinopyroxene have previously been reported from wells in the Salton Sea sediments (Helgeson 1968; McDowell and McCurry 1977), but their structures and compositions were not well documented. They occur in association with an assemblage of quartz-epidote-chlorite-microcline-albitebiotite-calcite-rutile or titanite, similar to assemblages in the greenschist facies (Zen and Thompson 1974). Because such materials occurred in an environment expected for pyriboles we have utilized the relatively high resolution capabilities of scanning and transmission electron microscopy coupled with analytical electron microscopy to characterize them, and have confirmed the primary growth of widechain pyriboles crystallizing under hydrothermal conditions corresponding to temperatures of the greenschist facies. 

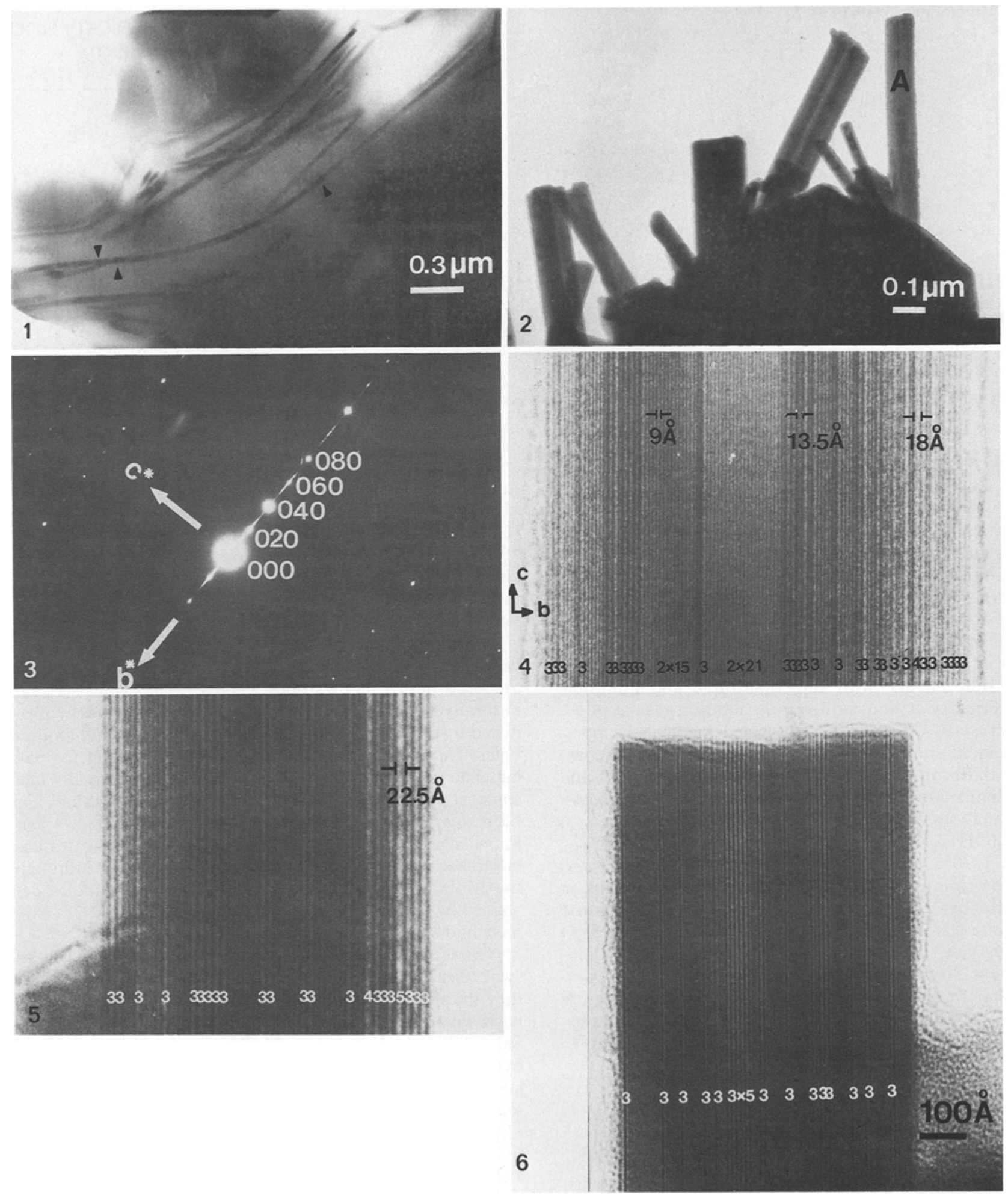

Fig. 1. Low magnification image showing pyribole fibers within casting resin. Arrows indicate apparent strain contrast in a curved fiber

Fig. 2. Low magnification image of ion-thinned edge, showing euhedral pyribole crystals superimposed on a mica crystal

Fig. 3. An electron diffraction pattern of pyribole from crystal A in Fig. 2 showing streaking parallel to $b^{*}$ due to irregular intercalation of different chain widths

Fig. 4. An a-axis lattice fringe image of part of the pyribole crystal A in Fig. 2. Irregular intercalation of double (2)-, triple (3)-, and quadruple (4)-chain widths in the b direction are shown

Fig. 5. Lattice fringe image of part of a pyribole fiber containing a quintuple (5)-chain unit. Unlabeled portions are double (2)-chain units

Fig. 6. Lattice fringe image showing straight external crystal edges and coherent boundaries between different chain widths 


\section{Sample characterization and experimental procedures}

The samples studied are siltstone and sandstone cuttings recovered from the No. 2 Imperial Irrigation District (IID No. 2) well in the Salton Sea Geothermal Field, Southern California. The geology of this area has been studied in detail by Muffler and Doe (1968) and the chemistry of the aqueous system by Helgeson (1968). The IID No. 2 well penetrated Pliocene and Pleistocene sand, silt, and clay deposits of the Colorado River to a depth of $1,547 \mathrm{~m}$. Under the elevated temperature and pressure of the geothermal system, sediments are actively undergoing transformation with conditions ranging from diagenesis to low-grade metamorphism corresponding to temperatures of the greenschist facies (Muffler and White 1969). McDowell and Elders (1980) further divided the overall progression of mineral assemblages in order of increasing depth (temperature) into four mineral zones: (1) dolomite/ankerite zone $\left(<190^{\circ} \mathrm{C}\right),(2)$ chlorite/calcite zone $\left(190-325^{\circ} \mathrm{C}\right),(3)$ biotite zone $\left(325-360^{\circ} \mathrm{C}\right)(4)$ andradite zone $\left(>360^{\circ} \mathrm{C}\right)$. The andradite zone of McDowell and Elders (1980) was not encountered in the IID No. 2 well. In addition, Yau et al. $(1983,1984)$ have separately described the diagenesis of illite and chlorite in shale samples in the same well. This paper is principally concerned with samples in the biotite zone.

Cuttings were impregnated with casting resin (Castolite-AC) to preserve the original textures, and ion-thinned by argon beam bombardment. The ion-thinned samples were then examined by scanning electron microscopy using backscattered imaging (SEM) operating at $15 \mathrm{kV}$ to identify the amphibole/pyroxene and other mineral phases associated with them within a $3 \mathrm{~mm}$ diameter area. One dimensional (010) and (100) lattice fringe images and selected area electron diffraction patterns were obtained using a JEOL JEM-100CX transmission electron microscope (TEM) with a sideentry stage operating at $100 \mathrm{kV}$. Chemical compositions were determined using an energy dispersive X-ray analysis system attached to the TEM. The analytical data were obtained by rastering the beam over a square area $(400 \times 400 \AA)$ for 100 seconds. Well analyzed ion-thinned clinochlore adularia, margarite and fayalite were used as standards for $\mathrm{Mg} / \mathrm{Si}, \mathrm{Al} / \mathrm{Si}, \mathrm{Ca} / \mathrm{Si}$ and $\mathrm{Fe} / \mathrm{Si}$, respectively. Procedures for preparation and analysis of samples are described in detail by Blake et al. (1980).

\section{Amphibole/wide-chain pyribole intergrowth}

Amphiboles were observed by TEM in siltstone samples from depths (temperatures) of $1,060 \mathrm{~m}\left(310^{\circ} \mathrm{C}\right), 1,384 \mathrm{~m}$ $\left(320^{\circ} \mathrm{C}\right)$, and $1,547 \mathrm{~m}\left(330^{\circ} \mathrm{C}\right)$, but were not found at depths shallower than $1,060 \mathrm{~m}$ despite lengthy observations of corresponding samples. They occur as disseminated fibrous crystals with typical diamond-shaped cross sections in pore space which is now filled with casting resin after impregnation during sample preparation (Fig. 1). The fibers are, on average, approximately $300 \AA\left(\| a^{*}\right)$ thick, $600 \AA$ $(\| b)$ wide and a few $\mu \mathrm{m}(\| c)$ long. They are usually too fine to be resolved by SEM. To a first approximation, there is no apparent variation in crystal size with depth. In some areas where the surrounding resin was thinned away, euhedral prismatic crystals stand out like skyscrapers (Fig. 2). The crystals usually exhibit sharp, straight and continuous edges parallel to the fiber direction.

An electron diffraction pattern from crystal A in Figure 2 shows the $b^{*} c^{*}$ reciprocal lattice plane (Fig. 3). Analogous electron diffraction patterns were obtained for other crystals. The patterns confirm that the long direction of the crystals is parallel to $c$, the direction of the tetrahedral chains. Indexing was accomplished using the lattice parameters and space group $(\mathrm{C} 2 / \mathrm{m})$ of clinoamphibole. The central $(0 \mathrm{k} 0)$ set of reflections displays diffuseness for reflections with $\mathrm{k}=4 \mathrm{n}+2$ but reflections with $\mathrm{k}=4 \mathrm{n}$ are relatively
Table 1. Chemical compositions and cation populations on the basis of a total of $8 \mathrm{Si}$ cations

\begin{tabular}{lcccc}
\hline Phase & \multicolumn{2}{l}{ Amphibole } & & Pyroxene \\
\hline $\mathrm{T}\left({ }^{\circ} \mathrm{C}\right)$ & 310 & 320 & 330 & 320 \\
\hline Depth $(\mathrm{m})$ & 1,060 & 1,384 & 1,547 & 1,515 \\
\hline \# analyses & 9 & 19 & 30 & 18 \\
\hline $\mathrm{Si}$ & 8.0 & 8.0 & 8.0 & 8.0 \\
$\mathrm{Mg}$ & 2.9 & 2.4 & 2.3 & 1.2 \\
$\mathrm{Fe}$ & 1.9 & 2.2 & 2.5 & 2.4 \\
$\mathrm{Mn}$ & 0.1 & $\operatorname{tr}$. & $\operatorname{tr}$. & $\operatorname{tr}$. \\
$\mathrm{Ti}$ & - & 0.1 & $\operatorname{tr}$. & - \\
$\mathrm{Al}$ & $\operatorname{tr}$. & $\operatorname{tr}$. & $\operatorname{tr}$. & $\operatorname{tr}$. \\
$\mathrm{Ca}$ & 1.8 & 2.0 & 2.0 & 4.4 \\
$\mathrm{O}$ & $21.8^{\mathrm{a}}$ & $21.8^{\mathrm{a}}$ & $21.8^{\mathrm{a}}$ & $24.0^{\mathrm{b}}$ \\
$\mathrm{OH}^{\mathrm{b}}$ & 1.8 & 2.0 & 2.0 & - \\
$\mathrm{M}^{\mathrm{c}}$ & 4.9 & 4.6 & 4.8 & 5.6 \\
\hline
\end{tabular}

a calculated on the basis of assumed composition of $67 \%$ actinolite and $33 \%$ triple-chain Ca-pyribole

b calculated for charge balance

c $\mathrm{M}=\mathrm{Mg}+\mathrm{Fe}+\mathrm{Mn}$

sharp. The streaking is due principally to the irregular intercalation of double-, triple- and wider-chain units. All chain units share a common subunit of $4.5 \AA$ (a single-chain unit) and therefore give rise to the sharp reflections having $\mathrm{k}=$ $4 n$, the differences between chain units being reflected in diffuseness for reflections with $k=4 n+2$.

Figure 4 shows an (010) lattice fringe image of the crystal which gave rise to the selected area diffraction pattern of Fig. 3. The image shows three kinds of spacing between pairs of dark fringes. They are designated as 2, 3 or 4, corresponding to the multiplicity in chain width. Similar features have been observed in samples from all three depths (Fig. 5, 6) in which wide-chain pyriboles were detected. The widths of the images in these figures correspond to the entire width of the crystals. The images show that the proportion of different chain types varies from crystal to crystal. The double-chain $(\sim 9 \AA)$ and triple-chain $(\sim 13.5 \AA)$ structures are most common and they occupy nearly all of the volume of a given crystal. Quadruple-chain $(\sim 18 \AA)$ and quintuple-chain $(\sim 22.5 \AA)$ structures are rare. As estimated from the limited number $(\sim 30)$ of crystals which yielded (010) lattice fringes, the volume ratio of double- to triple-chain structures is roughly $2: 1$. The proportion of chains of different widths appears to be the same in samples of all three depths. The double- and triple-chain slabs in all crystals are intercalated in an irregular manner. In all cases, the boundaries of $(010)$ fringes between two different chain units are coherent, straight boundaries, i.e. no dislocations or terminations of one chain type against another were observed. Diamond-shaped cross sections of two pyribole fibers within resin matrix are shown in Fig. 7. One (Fig. 7a) shows (010) lattice fringes which are identical to those shown above (Figs. 4-6), while the other shows (110) lattice fringes with a spacing of approximately $8.4 \AA$, corresponding to $\mathrm{d}_{(1 \mathrm{10})}$ of amphibole (Fig. $7 \mathrm{~b}$ ). The vertical contrast bands shown in Fig. $7 \mathrm{~b}$ resemble strain contrast features presumably arising from variations in chain width along (010) (Veblen personal communication) although the 

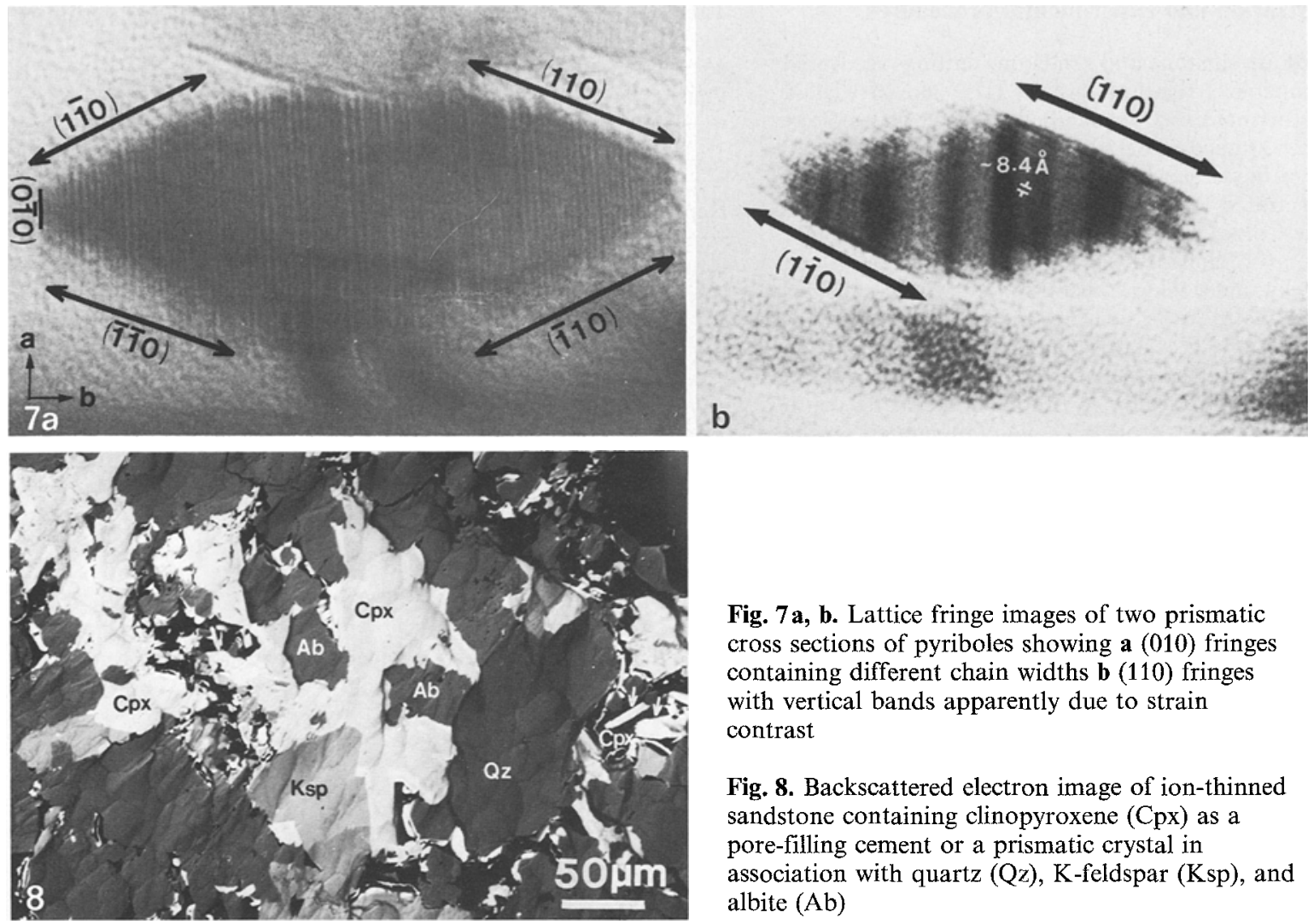

Fig. $7 \mathbf{a}, \mathbf{b}$. Lattice fringe images of two prismatic cross sections of pyriboles showing a (010) fringes containing different chain widths $\mathbf{b}(110)$ fringes with vertical bands apparently due to strain contrast

Fig. 8. Backscattered electron image of ion-thinned sandstone containing clinopyroxene ( $\mathrm{Cpx})$ as a pore-filling cement or a prismatic crystal in association with quartz (Qz), K-feldspar (Ksp), and albite $(\mathrm{Ab})$
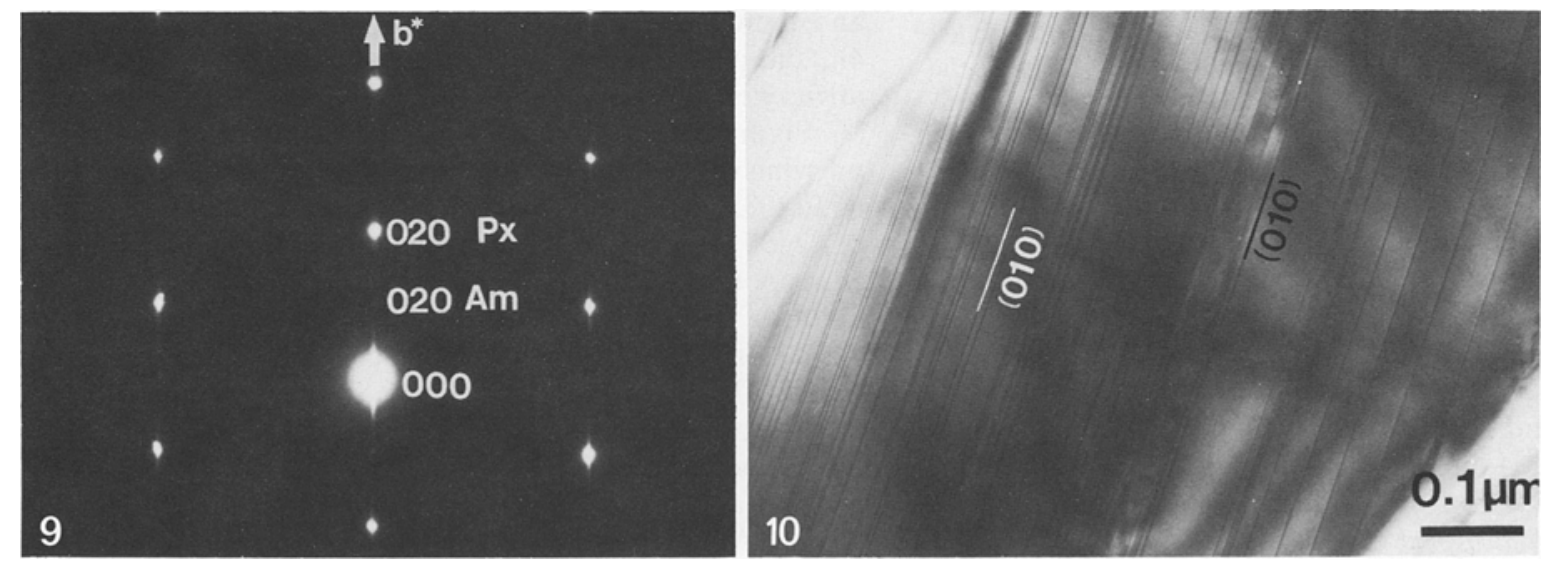

Fig. 9. An electron diffraction pattern of clinopyroxene showing streaking parallel to $b^{*}$ and a (020) reflection of amphibole

Fig. 10. Low magnification image of the grain which yields the diffraction pattern in Fig. 9 showing fine-lamellae intercalated parallel to $(010)$

contrast may also be derived from bending of crystals as shown in Fig. 1.

Although lattice fringe images and diffraction patterns both indicate that the crystals consist of wide-chain pyriboles, analytical data are required to identify their chemistry. Major peaks shown in the X-ray spectra of AEM analyses are due to $\mathrm{Mg}, \mathrm{Si}, \mathrm{Ca}$ and $\mathrm{Fe}$. Minor peaks correspond to $\mathrm{Al}, \mathrm{Mn}$ and $\mathrm{Ti}$. Na was not detected but the method is insensitive to the presence of $\mathrm{Na}$ and amounts of $0.1 \mathrm{Na}$ per formula or less would not be detected. Formulae given in Table 1 were normalized on the basis of a total of $8 \mathrm{Si}$ atoms. The data are averages of several analyses for each depth.

The analyses show that the total number of octahedral cations excluding $\mathrm{Ca}$ in fibrous amphiboles from all three depths is less than 5 , which is the value for an ideal $\mathrm{Ca}$ amphibole $\left(\mathrm{Ca}_{2} \mathrm{M}_{5} \mathrm{Si}_{8} \mathrm{O}_{22}(\mathrm{OH})_{2}, \mathrm{M}=\mathrm{Mg}, \mathrm{Fe}, \mathrm{Mn}, \mathrm{Ti}\right)$. The ideal structural formula of a pure $\mathrm{Ca}$ triple-chain silicate has the form: $\mathrm{CaM}_{4} \mathrm{Si}_{6} \mathrm{O}_{16}(\mathrm{OH})_{2}$ (Veblen and Burnham 1978; Akai 1982). Normalizing this to $8 \mathrm{Si}$ cations results in the formula $\mathrm{Ca}_{1.3} \mathrm{M}_{5.3} \mathrm{Si}_{8} \mathrm{O}_{21.3}(\mathrm{OH})_{2.7}$. The composition for a chain silicate containing $67 \%$ double-chain and $33 \%$ triple-chain units by volume should be $\mathrm{Ca}_{1.8} \mathrm{M}_{5.1} \mathrm{Si}_{8} \mathrm{O}_{21.8}$ $(\mathrm{OH})_{2.2}$ on the basis of $8 \mathrm{Si}$ cations. Our analyses show higher $\mathrm{Ca}$ and slightly lower $\mathrm{M}$ concentrations than the predicted composition, but the result is well within the precision of the analyses. The deviations may also reflect a different proportion of double-chain and triple-chain units 

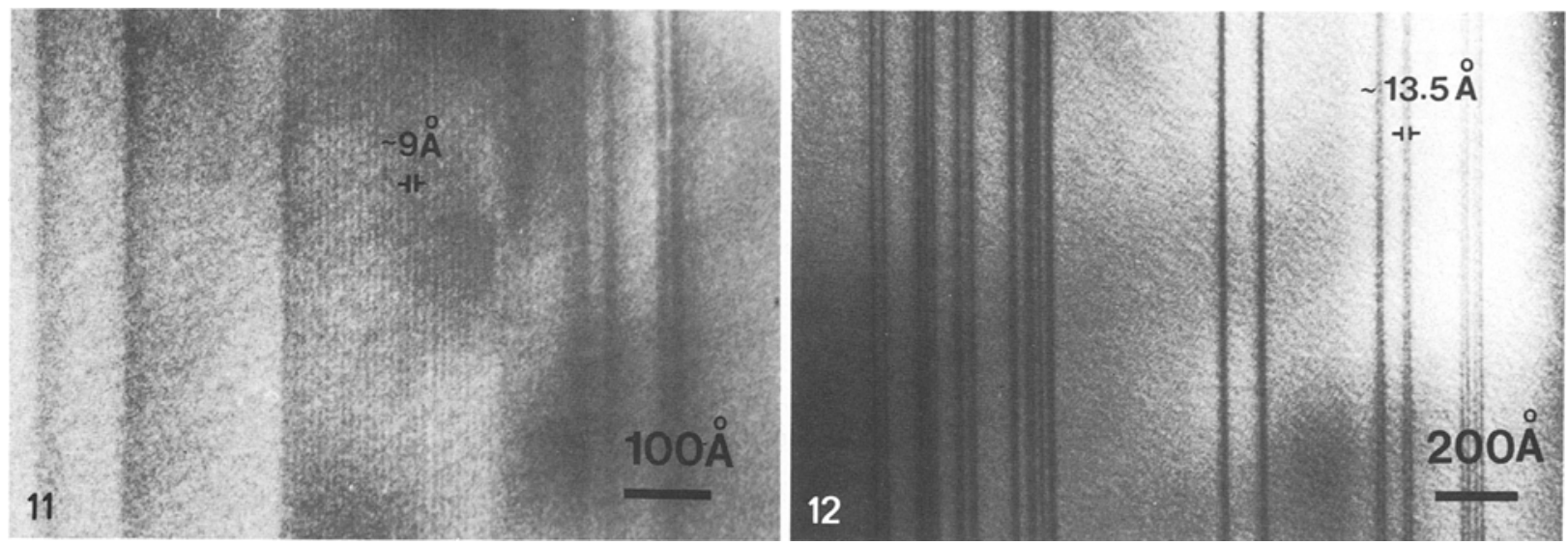

Fig. 11. High magnification image of part of the Cpx in Fig. 10 containing an amphibole lamella with fringes of $9 \AA$ spacing

Fig. 12. Irregular intercalation of triple chain widths within $\mathrm{Cpx}$

in the analyzed crystals. Chemical analyses could not be obtained for single phase slabs because their widths are too small to be resolved by the smallest effective beam size.

The analyses shown in Table 1 show that the $\mathrm{Mg} / \mathrm{Mg}+$ $\mathrm{Fe}$ ) ratio decreases with increasing depth (temperature). Such a trend may be related to the changing composition of pore fluids with increasing depth or to a change in original composition of sediments with depth. We presently have no way of evaluating these factors. However, this trend is also consistent with that generally observed for amphiboles in prograde metamorphic environments (Liou et al. 1974; Laird and Albee 1981).

\section{Clinopyroxene/amphibole/wide-chain pyribole intergrowths}

Clinopyroxenes were observed in IID No. 2 in sandstone cuttings at $1,384,1,445,1,515$ and $1,570 \mathrm{~m}$ and in veins in siltstone at $1,259,1,280$ and $1,515 \mathrm{~m}$. Temperatures encountered in these depths are in the range from 310 to $330^{\circ} \mathrm{C}$. The pyroxene occurs extensively as a pore-filling cement or in veins with uniform contrast in backscattered electron images (Fig. 8). Pyroxene also occasionally occurs as sub-idioblastic prismatic crystals approximately $20 \mu \mathrm{m}$ in maximum dimension.

The electron diffraction patterns from pyroxenes show streaking along the (0k0) reflections (Fig. 9). A weak but well-defined reflection maximum with a calculated spacing of approximating $9 \AA$ also occurred parallel to $b^{*}$, corresponding to $d_{(020)}$ of amphibole. All other well-defined reflections can be indexed as compatible with unit cell parameters and space group $\mathrm{C} 2 / \mathrm{c}$ of clinopyroxene. TEM images of the crystal which gave rise to the diffraction pattern of Fig. 9 show fine lamellae intercalated parallel to (010) within pyroxene (Fig. 10). At higher magnification, (010) lattice fringes of amphibole with a spacing of $9 \AA$ were observed within one of the lamellae (Fig. 11). Most other fine lamellae contain fringes having spacings of approximately $13.5 \AA$, corresponding to a triple-chain unit (Fig. 12). No fringes occur in the area occupied by the pyroxene because of the limited resolution of the instrument operated at $100 \mathrm{kV}$, which in practice cannot resolve the $4.5 \AA$ spacing $\left(d_{(020)}\right.$ of pyroxene). The boundaries between lamellae are straight and coherent and changes between types of chains along (010) were not observed.
EDS spectra for the pyroxene grain shown in Fig. 10 revealed major peaks due to $\mathrm{Si}, \mathrm{Ca}, \mathrm{Fe}$ and $\mathrm{Mg}$ and occasional minor peaks due to $\mathrm{Mn}$ and Al. Table 1 gives the average composition for the grain shown in Figure 10 calculated on the basis of $8 \mathrm{Si}$ atoms. The molar ratio $\mathrm{Fe} /(\mathrm{Fe}+$ $\mathrm{Mg}+\mathrm{Mn}$ ) of that grain is approximately 0.67 ; it is therefore ferrosilite. The formula is in good agreement with that of a pyroxene in which there are 8 octahedral cations per $8 \mathrm{Si}$ atoms although the $\mathrm{Ca}$ content is slightly in excess of the usual value of four, due probably to analytical error. To a first approximation, the proportion of single: double: triple chain units within the analyzed crystal is approximately $85: 5: 10 \%$ by volume. The calculated ideal formula for such a grain is $\mathrm{Ca}_{3.64}(\mathrm{Mg}, \mathrm{Fe})_{4.20} \mathrm{Si}_{8} \mathrm{O}_{23.64}(\mathrm{OH})_{0.36}$, for which the total of octahedral cations is 7.84 . The measured value of 8 cations is in good agreement with that value, within analytical error.

\section{Mineral assemblages and metamorphic reactions}

Minerals found in association with the amphiboles and clinopyroxenes in the Salton Sea samples are albite, K-feldspar, epidote, chlorite, biotite, calcite, quartz, and rutile or titanite. Most of these phases are believed to be of hydrothermal (authigenic) origin (Muffler and White 1969). Epidote is first observed at a depth of $1,000 \mathrm{~m}\left(300^{\circ} \mathrm{C}\right)$, increasing in amount to a depth of $1,384 \mathrm{~m}\left(320^{\circ} \mathrm{C}\right)$. AEM analyses of epidotes from the $1,060 \mathrm{~m}\left(310^{\circ} \mathrm{C}\right)$ sample yield an average composition of $\mathrm{Ca}_{2.1}\left(\mathrm{Al}_{1.9} \mathrm{Fe}_{0.8}\right) \mathrm{Si}_{3.2} \mathrm{O}_{10}(\mathrm{OH})$, which is similar to the EMPA analyses of epidotes formed at the same temperature in coarser-grained sandstones (McDowell and McCurry 1977). Authigenic chlorites appear first at much shallower depths $\left(384 \mathrm{~m}, 170^{\circ} \mathrm{C}\right)$. The greatest concentration of chlorite occurs at $1,000 \mathrm{~m}$ and then decreases slightly below that depth. The composition of chlorite from the $1,000 \mathrm{~m}\left(300^{\circ} \mathrm{C}\right)$ sample as analyzed by AEM is $\left(\mathrm{Mg}_{2.9} \mathrm{Fe}_{2.0} \mathrm{Al}_{1.0} \mathrm{Ca}_{0.1}\right)\left(\mathrm{Al}_{0.9} \mathrm{Si}_{3.1}\right) \mathrm{O}_{10}(\mathrm{OH})_{8}$, showing higher $\mathrm{Mg}$ and lower $\mathrm{Al}$ contents than obtained by EMPA analyses for chlorite from the same temperature interval in associated sandstones (McDowell and Elders 1980).

A number of reactions involving ferromagnesiam phyllosilicates, $\mathrm{Ca}-\mathrm{Al}$ hydrous silicates, carbonates and quartz have been proposed to explain the formation of actinolite 
Table 2. Thermodynamic data used in this study

\begin{tabular}{|c|c|c|c|c|c|c|c|c|}
\hline Phase & $G_{298}^{0}$ & $V_{298}^{0}$ & $S_{298}^{0}$ & A & $\mathrm{B}$ & $\mathrm{C}$ & $\mathrm{D}$ & \\
\hline Clinochlore (Chl) & $-8,290.85$ & 210.09 & 407.52 & 920.9821 & -139.4067 & 174.6192 & $-5,401.9628$ & 1 \\
\hline Tremolite $(\mathrm{Tr})$ & $-11,627.92$ & 272.92 & 548.90 & 832.0320 & 205.3550 & 109.8321 & $-4,925.3868$ & 1,4 \\
\hline Clinozoisite $(\mathrm{Cz})$ & $-6,495.01$ & 136.84 & 296.27 & 398.8248 & 171.9625 & 44.8648 & $-2,374.0480$ & 2,3 \\
\hline Anorthite (An) & $-4,002.21$ & 100.79 & 199.28 & 263.7033 & 62.8486 & 31.4700 & $-1,556.6829$ & 3 \\
\hline Quartz (Qz) & $-\quad 856.30$ & 22.69 & 41.46 & 73.4890 & 0.7849 & 15.3766 & -436.1435 & 1 \\
\hline Calcite (Cc) & $-1,131.18$ & 36.93 & 91.78 & 102.9147 & 23.4354 & 10.1186 & -607.0566 & 1 \\
\hline Diopside (Di) & $-3,036.55$ & 66.09 & 143.09 & 217.5963 & 35.9899 & 29.3705 & $-1,283.4240$ & 1 \\
\hline
\end{tabular}

$S_{\mathrm{T}}^{0}-S_{298}^{0}\left(\right.$ joules $/$ mole $\left.{ }^{\circ} \mathrm{K}\right)=\mathrm{A} \cdot \ln T+10^{-3} \mathrm{~B} \cdot T+10^{5} \mathrm{C} \cdot T^{-2}+\mathrm{D}$

1 Robie et al. (1978); 2 Perkins et al. (1980); 3 Robinson et al. (1982); 4 Krupka et al. (1985)

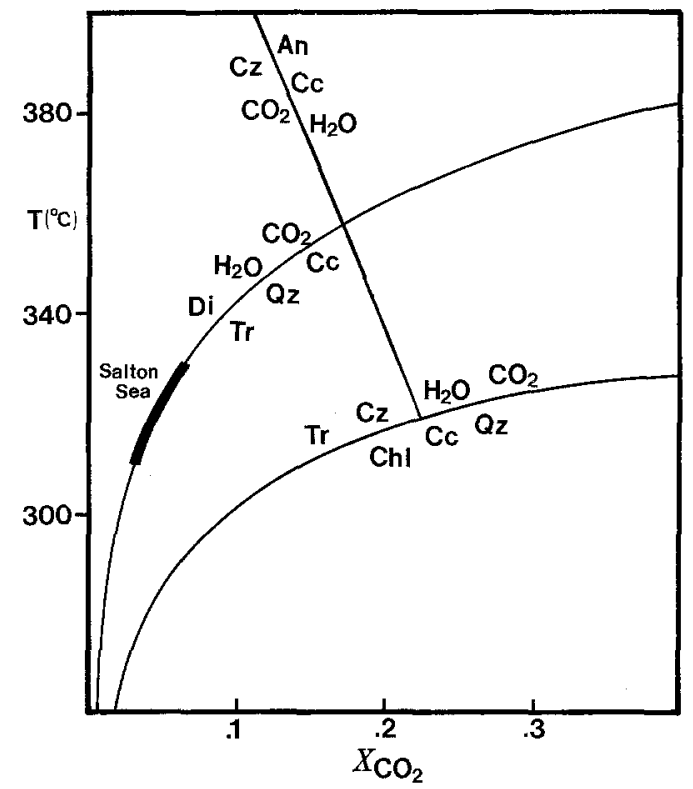

Fig. 13. $T-X$ phase equilibria calculated for end-member compositions at a measured fluid pressure of 100 bar. Reaction (1) was calculated by EQUIL, reaction (3) from the reversal at $1 \mathrm{~kb}$, $494^{\circ} \mathrm{C}, X_{\mathrm{CO}_{2}}=0.5$ (Slaughter et al. 1975) and corrected for solid solutions using a $K_{\mathrm{D}}=\left(\mathrm{X}_{\mathrm{Mg}} / \mathrm{X}_{\mathrm{Fe}}\right)^{\mathrm{Cpx}} /\left(\mathrm{X}_{\mathrm{Mg}} / \mathrm{X}_{\mathrm{Fe}}\right)^{\mathrm{Act}}=0.99 \quad($ Ferry 1976), and reaction of $2 \mathrm{Cz}+\mathrm{CO}_{2}=3 \mathrm{An}+\mathrm{Cc}+\mathrm{H}_{2} \mathrm{O}$ from the reversal at $5 \mathrm{~kb}, 650^{\circ} \mathrm{C}, \mathrm{X}_{\mathrm{CO}_{2}}=0.05$ (Storre et al. 1982). The darkened curve represents the $\mathrm{X}_{\mathrm{CO}_{2}}$ conditions at which both clinopyroxene and actinolite in Salton Sea samples are stable

in low grade metamorphic rocks (Hashimoto 1972). On the basis of the observed assemblages, a plausible reaction for actinolite formation in the Salton Sea sediments is:

$$
\begin{aligned}
& 3\left(\mathrm{Mg}_{5} \mathrm{Al}\right)\left(\mathrm{AlSi}_{3}\right) \mathrm{O}_{10}(\mathrm{OH})_{8}+10 \mathrm{CaCO}_{3}+21 \mathrm{SiO}_{2} \\
& \text { clinochlore } \\
& =3 \mathrm{Ca}_{2} \mathrm{Mg}_{5} \mathrm{Si}_{8} \mathrm{O}_{22}(\mathrm{OH})_{2}+2 \mathrm{Ca}_{2} \mathrm{Al}_{3} \mathrm{Si}_{3} \mathrm{O}_{12}(\mathrm{OH}) \\
& \text { tremolite } \\
& +8 \mathrm{H}_{2} \mathrm{O}+10 \mathrm{CO}_{2}
\end{aligned}
$$

A similar reaction:

$$
\begin{aligned}
& 12\left(\mathrm{Mg}_{5} \mathrm{Al}\right)\left(\mathrm{AlSi}_{3}\right) \mathrm{O}_{10}(\mathrm{OH})_{8} \\
& \text { clinochlore }
\end{aligned}
$$

may account for the formation of triple-chain $\mathrm{Ca}$ pyribole.
The formation of clinopyroxene may relate to the wellknown equilibrium reaction:

$$
\begin{aligned}
& 1 \mathrm{Ca}_{2} \mathrm{Mg}_{5} \mathrm{Si}_{8} \mathrm{O}_{22}(\mathrm{OH})_{2}+3 \mathrm{CaCO}_{3}+2 \mathrm{SiO}_{2} \\
& \text { tremolite } \\
& =\underset{\text { diopside }}{5 \mathrm{CaMgSi}_{2} \mathrm{O}_{6}}+\mathrm{H}_{2} \mathrm{O}+3 \mathrm{CO}_{2}
\end{aligned}
$$

The existence of a convecting fluid and the abundance of void space which typifies the Salton Sea samples implies that reactions occur via dissolution of reactants and precipitation of products rather than as reactions among solids as implied by the above equilibria. Nevertheless, the form of the above reactions does account for the observed mineral assemblages in the Salton Sea sediments.

Reactions (1) and (3) can be calculated in $\mathrm{P}-\mathrm{T}-\mathrm{X}$ space by utilizing thermodynamic data (Table 2). Due to the lack of thermodynamic data for wide-chain silicates, the equilibrium conditions for reaction (2) cannot be calculated. The equilibrium curves for reactions (1) and (3) were obtained using the program EQUILI (Wall and Essene unpublished), which is similar to that of Slaughter et al. (1976) (Fig. 13). The non-ideal mixing properties of $\mathrm{CO}_{2}$ and $\mathrm{H}_{2} \mathrm{O}$ were calculated from the model of Shmulovich et al. (1980). A fluid pressure of $100 \mathrm{bar}$, measured at casting perforations in IID No2 well (Helgeson 1967), was used for the calculation.

To apply reactions (1) and (3) to the Salton Sea assemblage, corrections must be made for the effects of solid solution in tremolite, clinozoisite, clinochlore and diopside. However, it is not possible to evaluate the activities of tremolite and diopside in the intercalated Salton Sea pyriboles due to the uncertain effects of intergrowths of wide-chain pyriboles. The activity of clinozoisite is also difficult to calculate because of the uncertainties in the contributions of order-disorder of $\mathrm{Fe} / \mathrm{Al}$ and a possible solvus at low temperatures. We have therefore chosen to use the end-member reactions as general approaches to evaluating the formation of actinolite and ferrosilite in the Salton Sea sediments. Nevertheless, the small effect of $\mathrm{Mg} / \mathrm{Fe}$ solid solutions on reaction (3) was estimated by using the $\mathrm{Mg} / \mathrm{Fe}$ partitioning coefficient between clinopyroxene and actinolite observed in greenschist facies rocks (Ferry 1976). The coexistence of amphibole and clinopyroxene constrains the value of $X_{\mathrm{CO}_{2}}$ within the range of $0.03-0.06$ at the inhole-measured temperatues of $310-330^{\circ} \mathrm{C}$ (Fig. 13). These values are in good agreement with the calculated $\mathrm{CO}_{2}$ fugacity $\left(\mathrm{CO}_{2}=\right.$ $2.5 \mathrm{~atm})$ at $1,000 \mathrm{~m}$ depth $\left(300^{\circ} \mathrm{C}\right)$ given by Helgeson (1967). Due to the lack of equilibrium experiments or thermodynamic data on triple-chain or wide-chain pyriboles, 
it is not known whether they have fields of stability or are produced metastably (Veblen and Buseck, 1979).

\section{Discussion}

The amphiboles and pyroxenes in the Salton Sea samples contain a disordered intercalation of a variety of chain width units. In nature, the wide-chain pyriboles have been observed only in metasomatized rock bodies where there has been alteration of pre-existing pyroxenes or amphiboles, as noted above. They were apparently formed at least in part by replacement mechanisms during which the parental pyroxene or amphibole structures were partly retained (Veblen 1981). In contrast, the euhedral crystal shapes of the fibrous amphiboles of the Salton Sea sediments indicate that they directly crystallized from solution. Although the pyroxenes described above are not usually euhedral, the absence of changes between types of chains, as commonly observed in altered pyroxenes (Veblen et al. 1980) indicates that the pyroxene/amphibole/wide-chain pyribole intergrowths may be due to primary growth. This is inconclusive, however, because coherent boundaries between different chain widths may also be a feature of intergrowths formed by alteration (Buseck et al. 1982). Nevertheless, the coexistence of fibrous euhedral amphibole and pyroxene as separate phases in pore spaces implies that both have formed from solution simultaneously and that the intergrowths are due to primary crystallization.

The relatively long dimension of the actinolite/widechain pyribole parallel to $c$ suggests that growth parallel to tetrahedral chains is much more rapid than lateral growth. The absence of dislocations, lack of changes in chain type within (010) slabs, and the absolutely straight and continuous outer crystal surfaces parallel to $(010)$ with no ledges at the scale of observation, all imply that growth is by propagation of ledges, which does not require the involvement of dislocations. Although conjectural, it seems reasonable to imagine that once the nucleation of a given chain type has been achieved, growth takes place by a rapid propagation parallel to the chain direction. Subsequent growth is then accomplished by nucleation of a new unit, either double- or triple-chain type on the previous (010) surface, which then propagates parallel to the chains. Local variations in solution chemistry may plausibly explain the nucleation of different chain types. Veblen and Buseck (1979) also suggested a significant and irregular fluctuation in composition over short distances to account for the occurrence of chain width disordering. They pointed out that chemical fluctuations are commonly observed in systems that are undergoing diffusion-controlled reactions. Chemical heterogeneity is especially likely in low temperature environments where diffusion rates are relatively slow and chemical equilibrium is seldom attained.

The reactions calculated for amphibole and pyroxene in the Salton Sea sediments show that their formation requires very water-rich conditions. Because the $\mathrm{CO}_{2}$ was generated by decarbonation reactions it must have constantly been diluted by water to such an extent that the mole fraction of $\mathrm{CO}_{2}$ remained low at all times. Such an extreme condition might be expected for the Salton Sea system because it is a system with circulating water. Crystals formed in low temperature environments are commonly found to contain a higher proportion of imperfections. This implies that the occurrence of wide-chain pyriboles may be much more common than previously thought. Amphiboles and pyroxenes in other low temperature prograde metamorphic environments should be carefully examined to evaluate the importance of wide-chain pyriboles in the formation and growth of amphiboles and pyroxenes.

Acknowledgement. We thank Dr. S. Douglas McDowell from Michigan Technological University for providing us with the specimens. We are indebted to Dr. David R. Veblen for critical reviews and to Dr. Wilbur C. Bigelow for maintaining the University of Michigan Microbeam Laboratory. This work was supported by NSF grant EAR-8107529 to Donald R. Peacor and the STEM used in this study was acquired under the Grant No. DMR-7709643 from the NSF.

\section{References}

Akai J (1982) Polymerization process of biopyribole in metasomatism at the Akatani ore deposit, Japan. Contrib Mineral Petrol $80: 117-131$

Blake DF, Allard LF, Peacor DR, Bigelow WC (1980) "Ultraclean" X-ray spectra in the JEOL JEM-100CX: Prox 38th Ann Mtg Electron Microsc Soc Am 136-137

Buseck PR, Nord GL, Jr, Veblen DR (1982) Subsolidus phenomena in pyroxenes. In: Ribbe PH (ed) Pyroxenes. Reviews in mineralogy. Mineral Soc Am 7:117-220

Chisholm JE (1973) Planar defects in fibrous amphiboles. J Mater Sci $8: 475-483$

Desnoyers C (1975) Exsolutions d'amphibole, de grenat et de spinelle dans les pyroxenes de roches ultrabasiques: peridotite et pyroxenolites. Bull Soc Fr Mineral Cristallogr 98:65-77

Drits VA, Goncharov YI, Aleksandrova VA, Khadzhi VE, Dmitrik AL (1975) New type of strip silicate. Sov Phys Crystallogr 19:737-741

Ferry JM (1976) P, t, $\mathrm{f}_{\mathrm{CO}_{2}}$, and $\mathrm{f}_{\mathrm{H}_{2} \mathrm{O}}$ during metamorphism of calcareous sediments in the Waterville-Vassalboro area, South-Central Maine. Contrib Mineral Petrol 57:119-143

Hashimoto M (1972) Reactions producing actinolite in basic metamorphic rocks. Lithos 5:19-31

Helgeson HC (1967) Solution chemistry and metamorphism. In: Abelson PH (ed) Researches in geochemistry, vol 2. John Wiley \& Sons, New York, pp 362-404

Helgeson HC (1968) Geologic and thermodynamic characteristics of the Salton Sea geothermal system. Am J Sci 266:129-166

Hutchison JL, Irusteta MC, Whittaker EJW (1975) High resolution electron microscopy and diffraction studies of fibrous amphiboles. Acta Crystallogr Sect A 31:794-801

Jefferson DA, Mallinson LG, Thomas JM (1976) Structural irregularities in nephrite jade; an electron microscope study. Mater Res Bull 11:1557-1562

Jefferson DA, Mallinson LG, Hutchison JL, Thomas JM (1978) Multiple-chain and unusual faults in amphiboles. Contrib Mineral Petrol 66:1-4

Krupka KM, Hemingway BS, Robie RA, Kerrick DM (1985) High-temperature heat capacities and derived thermodynamic properties of anthophyllite, diopside, dolomite, enstatite, bronzite, talc, tremolite, and wollastonite. Am Mineral 70:261-271

Laird J, Albee AL (1981) Pressure, temperature and time indicators in mafic schist: Their application to reconstructing the polymorphic history of Vermont. Am J Sci $281: 127-175$

Liou JG, Kuniyoshi S, Ito K (1974) Experimental studies of the phase relations between greenschist and amphibolite in a basaltic system. Am J Sci 274:613-632

Maresch WV, Czank M (1983a) Phase characterization of synthetic amphiboles on the join $\mathrm{Mn}^{2+} \mathrm{Mg}_{7-x}\left(\mathrm{Si}_{8} \mathrm{O}_{22}\right)(\mathrm{OH})_{2}$. Am Mineral 68:744-753

Maresch WV, Czank M (1983b) Problems of compositional and structural uncertainty in synthetic hydroxyl-amphiboles; with an annotated altas of the realbau. Period Mineral 52:463-542

McDowell SD, McCurry MO (1977) Active metamorphism in the 
Salton Sea Geothermal Field, California: Geol Soc Am Abstr Prog 9:108

McDowell SD, Elders WA (1980) Authigenic layer silicate minerals in borehole Elmore 1, Salton Sea Geothermal Field, California, USA. Contrib Mineral Petrol 74:293-310

Muffler LJP, Doe BR (1968) Composition and mean age of detritus of the Colorado River delta in the Salton Sea Trough, Southeastern California. J Sediment Petrol 38:384-399

Muffler LJP, White DW (1969) Active metamorphism of upper Cenozoic sediments in the Salton Sea geothermal field and the Salton Trough, Southeastern California. Geol Soc Am Bul $80: 157-182$

Nakajima Y, Ribbe PH (1981) Texture and structural interpretation of the alteration of pyroxene to other biopyriboles. Contrib Mineral Petrol 78:230-239

Nissen HU, Wessicken R, Woensdregt CF, Pfeifer HR (1980) Disordered intermediates between jimthompsonite and anthophyllite from the Swiss Alps. Inst Phys Conf Ser 52:99-100

Perkins D, Westrum EF Jr, Essene EJ (1980) The thermodynamic properties and phase relations of some minerals in the system $\mathrm{CaO}-\mathrm{Al}_{2} \mathrm{O}_{3}-\mathrm{SiO}_{2}-\mathrm{H}_{2} \mathrm{O}$. Geochim Cosmochim Acta 44:61-84

Robie RA, Hemingway BS, Fisher JR (1978) Thermodynamic properties of minerals and related substances at $298.15 \mathrm{~K}$ and 1 bar (10 pascals) pressure and at higher temperatures. US Geol Surv Bull 1452

Robinson GR Jr, Haas JL Jr, Schafer CM, Haselton HT Jr (1982) Thermodynamic and thermophysical properties of selected phases in the $\mathrm{MgO}-\mathrm{SiO}_{2}-\mathrm{H}_{2} \mathrm{O}-\mathrm{CO}_{2}, \mathrm{CaO}-\mathrm{Al}_{2} \mathrm{O}_{3}-$ $\mathrm{SiO}_{2}-\mathrm{H}_{2} \mathrm{O}-\mathrm{CO}_{2}$, and $\mathrm{Fe}-\mathrm{FeO}-\mathrm{Fe}_{2} \mathrm{O}_{3}-\mathrm{SiO}_{2}$ chemical systems, with special emphasis on the properties of basalts and their mineral components. US Geol Surv Open-File Rept 83

Shmulovich KI, Shmonov VM, Mazur VA, Kalinichev AG (1980) $\mathrm{P}-\mathrm{V}-\mathrm{T}$ and activity concentration relations in the $\mathrm{H}_{2} \mathrm{O}-\mathrm{CO}_{2}$ systems (homogeneous solutions). Geochem Int 17:123-129

Slaughter J, Kerrick DM, Wall VJ (1975) Experimental and thermodynamic study of equilibria in the system $\mathrm{CaO}-\mathrm{MgO}-$ $\mathrm{SiO}_{2}-\mathrm{H}_{2} \mathrm{O}-\mathrm{CO}_{2}$. Am J Sci 275:143-162

Slaughter J, Wall VJ, Kerrick DM (1976) APL computer programs for thermodynamic calculations of $\mathrm{P}-\mathrm{T}-\mathrm{X}_{\mathrm{CO}_{2}}$ space. Contrib Mineral Petrol 54:157-171
Smith PPK (1977) An electron microscope study of amphibole lamellae in augite. Contrib Mineral Petrol 59:317-322

Storre B, Johannes W, Nitsch KH (1982) The stability of zoisite in $\mathrm{H}_{2} \mathrm{O}-\mathrm{CO}_{2}$ mixtures. Neues Jahrb Mineral Monatsh 9:395-406

Tateyama H, Shimoda S, Sudo T (1978) Synthesis and crystal structure of a triple chain silicate, $\mathrm{Na}_{2} \mathrm{Mg}_{4} \mathrm{Si}_{6} \mathrm{O}_{16}(\mathrm{OH})_{2}$. Contrib Mineral Petrol 66:146-156

Thompson JB Jr (1870) Geometrical possibilities for amphibole structure: model biopyriboles. Am Mineral 55:292-293

Thompson JB Jr (1978) Biopyriboles and polysomatic series. Am Mineral 63:239-249

Veblen DR, Buseck PR, Burnham CW (1977) Asbestiform chain silicates: new minerals and structural groups. Science 198:359-365

Veblen DR, Burnham CW (1978) New biopyriboles from Chester, Vermont. II. The crystal chemistry of jimthompsonite, clinojimthompsonite and chesterite, and the amphibole-mica reaction. Am Mineral 63:1053-1073

Veblen DR, Buseck PR (1979) Chain-width order and disorder in biopyriboles. Am Mineral 64:687-700

Veblen DR, Buseck PR (1980) Microstructures and reaction mechanisms in biopyriboles. Am Mineral 65:599-623

Veblen DR (1981) Non-classical pyriboles and polysomatic reactions in biopyriboles. In: Veblen DR (ed) Amphibole and other hydrous pyriboles - mineralogy. Reviews in Mineralogy Vol 9A. Mineral Soc Am, Washington, DC, pp 189-236

Veblen DR, Buseck PR (1981) Hydrous pyriboles and sheet silicates in pyroxenes and uralites: intergrowth microstructures and reaction mechanisms. Am Mineral 66:1107-1134

Yau LYC, Lee JH, Peacor DR, McDowell SD (1983) TEM study of illite diagenesis in shale of the Salton Sea Geothermal Field, California. Clay Minerals Soc Abstr Prog 20:42

Yau YC, Peacor DR, McDowell SD (1984) TEM/AEM study of chlorite diagenesis in well IID No 2 in Salton Sea Geothermal Field, California. Clay Minerals Soc Abstr Prog 21:120

Zen EA, Thompson AB (1974) Low grade regional metamorphism: mineral equilibrium relations. Annu Rev Earth Planet Sci $2: 179-212$

Received September 30, 1985 / Accepted May 14, 1986 